Ilmu Pertanian (Agricultural Science)

Vol. 2 No. 1 April, 2017 : 020-028

Available online at http://journal.ugm.ac.id/jip

DOI: doi.org/10.22146/ipas.17700

\title{
The Effect of Various Weedy Periods on Growth and Yield of Soybean in Agroforestry System with Kayu Putih
}

\author{
Joko Budi Santoso Nugroho ${ }^{1 *}$, Endang Sulistyaningsih ${ }^{1}$, Priyono Suryanto ${ }^{2}$ \\ ${ }^{1}$ Department of Agronomy, Faculty of Agriculture, Universitas Gadjah Mada \\ Jln. Flora no. 1, Bulaksumur, Sleman, Yogyakarta 5528, Indonesia \\ ${ }^{2}$ Department of Silviculture, Faculty of Forestry, Universitas Gadjah Mada \\ Jln. Agro no. 1, Bulaksumur, Sleman, Yogyakarta 55281, Indonesia \\ *Corresponding email: jokobsn@mail.ugm.ac.id
}

\begin{abstract}
Received: $5^{\text {th }}$ January 2017 ; Revised: $25^{\text {th }}$ August 2017 ; Accepted: $28^{\text {th }}$ August 2017
ABSTRACT

This study was aimed to detect the effect of various treatment periods of weedy on the growth and yield of soybean; and to determine the most appropriate time periods of weedy for soybean in agroforestry systems with kayu putih. The experiment had been conducted in Menggoran, BDH Playen, KPH Yogyakarta, Gunungkidul Regency, Special Province of Yogyakarta from February 28 to May 9, 2015. Randomized Complete Block Design (RCBD) with three blocks as replications waas applied in this experiment. The treatments were weedy periods on $0,14,28,42$, and 56 days after planting (dap) and weed-free period on $0,14,28,42$, and 56 dap. The results showed that there were significant differences in the soil moisture content, root surface area, root length, chlorophyll content, root dry weight, shoot dry weight, dry weight of soybean seeds, and weed dry weight. The highest seed weight per hectare was found in weedfree until harvest treatment but it was not significantly different from weedy periods after 56 dap and weed-free after 14 dap. The effective periods of weedy time for soybean in agroforestry systems with kayu putih began at 28 dap - 56 dap.
\end{abstract}

Keywords: Agroforestry, Kayu Putih, Soybean, Weed, Weedy Periods

\section{INTRODUCTION}

The soybean production is steadily declining over the last five years (BPS, 2014). The unavailability of land becomes a major factor in crop productivity in order to supply the food demand. Utilisation of available land among forest plants becomes an alternative that can be used for planting annual crops, where the combination can scheme a system, called as agroforestry. This system becomes one of the land management systems to overcome the land productivity.

The land between kayu putih plants in the forest has a potency for annual crops. The approach by location specific system on kayu putih plant which forms alley cropping can be used for optimalising the land productivity. The combination between kayu putih plants with annual crop can be seen in the resources sharing, where the kayu putih plant influences the annual plant through resource changes, such as light, nutrition, and water (Scholes and Walker, 1993). The establishment of agroforestry systems can be a basis to increase the value of land; in this case, the proper cultivation techniques need to be included in. Intercropping cultivation system becomes a valuable system in order to improve land productivity and farmers income per unit area in unit time. It also can provide optimum yield in terms of production, because it is composed of several commodities that build a sustainable system (Johu et al., 2002).

One way to increase the productivity and economic value of soybean cultivation is by controlling weeds in its field, since weed can reduce the production of cultivated plants. Weeds are a serious constraint to easy harvesting in soybean and can reduce yields and economic returns. Thus, weed control is considered a key factor for successful soybean production. Various weed management systems have been developed for that purpose.

The main competion factor between soybean and weed is solar radiation, water, and nutrients. According to Moenandir (1993), weeding exact timing will be able to reduce the number of weeds which grown and shorten the competition. In plant life cycle, not all growth stages of crop is susceptible to weed 
competition. Approximately, $25-33 \%$ of the first annual plant life cycle is the most critical competition period to weed. There is a false assumption that weeding in any time during plant growth will solve weed competition problem (Zimdahl, 1980). The critical period of weed control (CPWC) indicates the optimum time for applying weed control measure (Cardoso et al., 2011). Therefore, information on these periods can be effective to improve the efficiency of weed management practices (Hall et al., 1992; Amador-Ramírez, 2002; Bukun, 2004).

For better yield and quality, controlling weeds during the critical period of crop growth is important. Identification of CPWC in major crops is one of the first step in designing a successful integrated weed management (IWM) program (Swanton and Weise, 1991; Knezevic et al., 2003) and the use of critical period threshold model will assists in improved farm level decision making (Zimdahl, 1988; Zimdahl, 1993). The CPWC is the length of time that the crop must be kept weed-free to prevent yield loss at a certain level (Weaver and Tan, 1983; Knezevic et al., 2003). The CPWC is determined by measuring the time interval between two separately measured crop-weed competition components: (i) the critical duration of weed interference, and (ii) the critical weed-free period (Weaver and Tan, 1983; Knezevic et al., 2003).

The critical duration of weed interference is defined as the maximum length of time early emerging weeds which can interfere with the crop without causing any unacceptable yield loss (Weaver and Tan, 1983; Knezevic et al., 2003). The critical weed-free period is defined as the minimum length of required time for the crop to be maintained weed-free before yield loss caused by late emerging weeds is of no practical concern (Weaver and Tan, 1983; Knezevic et al., 2003). From a practical standpoint, yield losses caused by weed interference before or after the CPWC will be of limited interest (Knezevic et al., 2003). Many studies have been conducted worldwide to determine the CPWC in various crops under a range of environmental conditions (Evans et al., 2003; Knezevic et al., 2003; Van Acker et al., 1993; Arslan et al., 2006; Uremis et al., 2009; Knezevic et al., 2013; Tursun et al., 2015; Tursun et al., 2016).

Studies conducted in different crops under diversified environmental conditions might not be applicable to all kind of systems due to location differences, including soil and climatic conditions, as well as weed populations (Van Acker et al., 1993; Evans et al., 2003; Knezevic et al., 2003; Bukun, 2004; Tursun et al., 2015; Tursun et al., 2016). According to Hendrival et al. (2014), critical period of soybean crop in the paddy field after rice plantation to weed competition occurred on 2-6 week after planting.

Therefore, this study aims to understand the effect of various treatment periods of weedy on the growth and yield of soybean and to determine the most appropriate time periods of weedy for soybean in agroforestry systems with kayu putih.

\section{MATERIALS AND METHODS}

This study aimed to understand the effect of various treatment periods of weedy on the growth and yield of soybean and to determine the most appropriate time periods of weedy for soybean in agroforestry systems with kayu putih. The experiment had been conducted in Menggoran, BDH Playen, KPH Yogyakarta, Gunungkidul Regency, Special Province of Yogyakarta from February 28 to May 9, 2015. The experiment used a single factor randomized complete block design (RCBD) with three blocks as replications. The treatments were the weedy periods in soybean which consisted of ten levels (Table 1)

The observations were made on the variables of soil moisture content, leaf area, root surface area, root length, chlorophyll content, root dry weight, shoot dry weight, dry weight, dry weight of weeds and soybean seeds. Calculations were performed using PROC GLM ANOVA with SAS for Windows 9.0 software (SAS Institute, 1994). If ANOVA showed that $\mathrm{F}$ calculate $>\mathrm{F}$ table, it meant that there was a significant difference among treatments, then would be followed by Duncan's Multiple Range Test (DMRT) $\alpha 5 \%$. To determine the relationship between weed dry weight and grain yield of soybean, a simple linear regression analysis was done. The simple linear regression analysis was done using SAS PROC REG with SAS for Windows 9.0 (SAS Institute, 1994).

Table 1. Weedy and weed-free periods of treatment

\begin{tabular}{cll}
\hline No & \multicolumn{1}{c}{ Treatment } & \multicolumn{1}{c}{ Remarks } \\
\hline 1 & W - 0 dap & Weedy until harvest \\
2 & W - 14 dap & Weedy after 14 dap \\
3 & W - 28 dap & Weedy after 28 dap \\
4 & W - 42 dap & Weedy after 42 dap \\
5 & W - 56 dap & Weedy after 56 dap \\
6 & WF - 14 dap & Weed-free after 14 dap \\
7 & WF - 28 dap & Weed-free after 28 dap \\
8 & WF - 42 dap & Weed-free after 42 dap \\
9 & WF - 56 dap & Weed-free after 56 dap \\
10 & WF - 0 dap & Weed-free until harvest \\
\hline
\end{tabular}


Table 2. Soil moisture content on various weedy periods of soybean in agroforestry system with kayu putih

\begin{tabular}{lccccc}
\hline \multirow{2}{*}{ Treatment } & \multicolumn{5}{c}{ Soil Moisture Content (\%) } \\
\cline { 2 - 6 } W - 0 dap & 40 dap & 28 dap & 42 dap & 56 dap & 70 dap \\
W - 14 dap & $41.67 \mathrm{bcd}$ & $44.43 \mathrm{c}$ & $44.85 \mathrm{c}$ & $41.56 \mathrm{~d}$ & $35.35 \mathrm{~cd}$ \\
W - 28 dap & $40.17 \mathrm{~d}$ & $42.57 \mathrm{c}$ & $44.27 \mathrm{c}$ & $40.67 \mathrm{~d}$ & $34.77 \mathrm{~d}$ \\
W - 42 dap & $41.01 \mathrm{~cd}$ & $44.04 \mathrm{bc}$ & $45.59 \mathrm{bc}$ & $42.09 \mathrm{~cd}$ & $35.62 \mathrm{~cd}$ \\
W - 56 dap & $43.18 \mathrm{bc}$ & $45.97 \mathrm{~b}$ & $47.16 \mathrm{~b}$ & $44.09 \mathrm{bc}$ & $37.68 \mathrm{bc}$ \\
WF - 14 dap & $44.16 \mathrm{ab}$ & $46.20 \mathrm{~b}$ & $47.21 \mathrm{~b}$ & $44.55 \mathrm{~b}$ & $38.64 \mathrm{ab}$ \\
WF - 28 dap & $40.88 \mathrm{~cd}$ & $43.43 \mathrm{c}$ & $45.20 \mathrm{c}$ & $41.56 \mathrm{~d}$ & $35.46 \mathrm{~cd}$ \\
WF - 42 dap & $40.80 \mathrm{~cd}$ & $43.04 \mathrm{c}$ & $44.80 \mathrm{c}$ & $41.21 \mathrm{~d}$ & $35.36 \mathrm{~cd}$ \\
WF - 56 dap & $40.81 \mathrm{~cd}$ & $43.25 \mathrm{c}$ & $44.90 \mathrm{c}$ & $41.27 \mathrm{~d}$ & $35.37 \mathrm{~cd}$ \\
WF - 0 dap & $46.90 \mathrm{a}$ & $48.89 \mathrm{a}$ & $50.79 \mathrm{a}$ & $47.15 \mathrm{a}$ & $40.89 \mathrm{a}$ \\
\hline Average & 42.01 & 44.48 & 46.06 & 42.61 & 36.54 \\
\hline CV (\%) & 3.64 & 2.72 & 2.06 & 3.04 & 4.00 \\
\hline
\end{tabular}

Remarks: Number followed by the same letter in the same coloumn indicated that there was no significant difference based on DMRT $\alpha 5 \%$ test; W: weedy after $n$ dap; WF: weed-free after $n$ dap.

Table 3. Leaf area on various weedy periods of soybean in agroforestry system with kayu putih

\begin{tabular}{lccccc}
\hline \multirow{2}{*}{ Treatment } & \multicolumn{5}{c}{ Leaf Area $\left(\mathrm{cm}^{2}\right)$} \\
\cline { 2 - 6 } W - 0 dap & 14 dap & 28 dap & 42 dap & 56 dap & 70 dap \\
W - 14 dap & $104.81 \mathrm{ab}$ & $521.8 \mathrm{a}$ & $782.6 \mathrm{a}$ & $1043.5 \mathrm{a}$ & $939.2 \mathrm{a}$ \\
W - 28 dap & $78.92 \mathrm{~b}$ & $459.6 \mathrm{a}$ & $689.4 \mathrm{a}$ & $919.2 \mathrm{a}$ & $827.2 \mathrm{a}$ \\
W - 42 dap & $79.37 \mathrm{~b}$ & $536.2 \mathrm{a}$ & $804.4 \mathrm{a}$ & $1072.5 \mathrm{a}$ & $959.8 \mathrm{a}$ \\
W - 56 dap & $81.74 \mathrm{~b}$ & $429.3 \mathrm{a}$ & $633.4 \mathrm{a}$ & $863.8 \mathrm{a}$ & $748.6 \mathrm{a}$ \\
WF - 14 dap & $113.69 \mathrm{ab}$ & $556.7 \mathrm{a}$ & $804.1 \mathrm{a}$ & $1096.5 \mathrm{a}$ & $950.3 \mathrm{a}$ \\
WF - 28 dap & $80.55 \mathrm{~b}$ & $533.0 \mathrm{a}$ & $769.8 \mathrm{a}$ & $1049.8 \mathrm{a}$ & $898.2 \mathrm{a}$ \\
WF - 42 dap & $91.85 \mathrm{~b}$ & $688.8 \mathrm{a}$ & $964.4 \mathrm{a}$ & $1315.1 \mathrm{a}$ & $11251 \mathrm{a}$ \\
WF - 56 dap & $129.12 \mathrm{ab}$ & $494.1 \mathrm{a}$ & $691.7 \mathrm{a}$ & $943.2 \mathrm{a}$ & $807.0 \mathrm{a}$ \\
WF - 0 dap & $168.73 \mathrm{a}$ & $610.0 \mathrm{a}$ & $854.0 \mathrm{a}$ & $1164.5 \mathrm{a}$ & $996.3 \mathrm{a}$ \\
\hline Average & 101.89 & 526.30 & 764.41 & 1033.51 & 903.21 \\
\hline CV (\%) & 39.55 & 30.98 & 30.46 & 30.65 & 30.32 \\
\hline Rem
\end{tabular}

Remarks: Number followed by the same letter in the same coloumn indicated that there was no significant difference based on DMRT $\alpha 5 \%$ test; W: weedy after $n$ dap; WF: weed-free after $n$ dap.

\section{RESULT AND DISCUSSION}

Soil conditions at the study site had ustic moisture regime. Ustic moisture regime was a regime which had limited moisture content, but it was available at the time when the environmental conditions was suitable for plant growth (Soil Survey Staff, 2010). Based on the interpretation of soil horizons in each soil profile, it was known that the soil at the site fell under Lithic Haplusterts type. It was a vertisol soil type with a shallow solum and lithic contact within $50 \mathrm{~cm}$ of the soil surface (Soil Survey Staff, 2010). Based on the field observation and laboratory test, the soil in the research location was known to be dominated by clay fraction for $75.17 \%$, which could be classified as clay texture. The bulk density was $1.14 \mathrm{~g} / \mathrm{cm}^{3}$ with a permeability of $0 \mathrm{~cm} /$ hour and very slow value due to the high clay content which resulted in a very low porosity. The nutrient content in the research location showed a varied status from very low until very high status with neutral $\mathrm{pH}$.

Soil moisture was very important to the nutrient absorption processes and translocation for plants. The soil moisture condition affected the availability of nutrient in the soil and nutrient absorption by plants (Kramer, 1969).

The result of variance (Table 2) showed that there were 
Table 4. Chlorophyll content on various weedy periods of soybean in agroforestry system with kayu putih

\begin{tabular}{lccc}
\hline \multirow{2}{*}{ Treatment } & \multicolumn{3}{c}{ Chlorophyll Content } \\
\cline { 2 - 4 } & a chlorophyll & b chlorophyll & Total chlorophyll \\
\hline W - 0 dap & $0.43 \mathrm{~d}$ & $0.30 \mathrm{e}$ & $0.73 \mathrm{e}$ \\
W - 14 dap & $0.49 \mathrm{bc}$ & $0.33 \mathrm{~d}$ & $0.82 \mathrm{~d}$ \\
W - 28 dap & $0.49 \mathrm{bc}$ & $0.33 \mathrm{~d}$ & $0.83 \mathrm{~d}$ \\
W - 42 dap & $0.50 \mathrm{abc}$ & $0.40 \mathrm{c}$ & $0.90 \mathrm{bc}$ \\
W - 56 dap & $0.52 \mathrm{ab}$ & $0.42 \mathrm{bc}$ & $0.94 \mathrm{bc}$ \\
WF - 14 dap & $0.52 \mathrm{ab}$ & $0.45 \mathrm{~b}$ & $0.97 \mathrm{ab}$ \\
WF - 28 dap & $0.49 \mathrm{bc}$ & $0.43 \mathrm{~b}$ & $0.92 \mathrm{bc}$ \\
WF - 42 dap & $0.47 \mathrm{c}$ & $0.42 \mathrm{bc}$ & $0.89 \mathrm{c}$ \\
WF - 56 dap & $0.46 \mathrm{~cd}$ & $0.44 \mathrm{~b}$ & $0.91 \mathrm{bc}$ \\
WF - 0 dap & $0.54 \mathrm{a}$ & $0.49 \mathrm{a}$ & $1.03 \mathrm{a}$ \\
\hline Average & 0.49 & 0.40 & 0.90 \\
\hline CV (\%) & 4.41 & 4.36 & 4.26 \\
\hline
\end{tabular}

Remarks: Number followed by the same letter in the same coloumn indicated that there was no significant difference based on DMRT $\alpha 5 \%$ test; W: weedy after $n$ dap; WF: weed-free after $n$ dap.

Table 5. Root surface area on various weedy periods of soybean in agroforestry system with kayu putih

\begin{tabular}{lccccc}
\hline \multirow{2}{*}{ Treatment } & \multicolumn{5}{c}{ Root Surface Area $\left(\mathrm{cm}^{2}\right)$} \\
\cline { 2 - 6 } W - 0 dap & 14 dap & 28 dap & 42 dap & 56 dap & 70 dap \\
W - 14 dap & $80.35 \mathrm{~cd}$ & $142.43 \mathrm{e}$ & $231.51 \mathrm{e}$ & $234.98 \mathrm{e}$ & $237.33 \mathrm{e}$ \\
W - 28 dap & $81.76 \mathrm{~cd}$ & $228.81 \mathrm{~cd}$ & $369.42 \mathrm{~cd}$ & $381.31 \mathrm{~cd}$ & $386.59 \mathrm{~cd}$ \\
W - 42 dap & $90.78 \mathrm{bc}$ & $246.15 \mathrm{bc}$ & $412.69 \mathrm{bc}$ & $428.18 \mathrm{bc}$ & $435.57 \mathrm{bc}$ \\
W - 56 dap & $96.76 \mathrm{bc}$ & $257.60 \mathrm{bc}$ & $483.80 \mathrm{ab}$ & $495.90 \mathrm{ab}$ & $505.81 \mathrm{ab}$ \\
WF - 14 dap & $108.09 \mathrm{~b}$ & $278.89 \mathrm{~b}$ & $493.64 \mathrm{ab}$ & $515.16 \mathrm{ab}$ & $525.62 \mathrm{ab}$ \\
WF - 28 dap & $78.27 \mathrm{~cd}$ & $222.14 \mathrm{~cd}$ & $355.58 \mathrm{~cd}$ & $366.81 \mathrm{~cd}$ & $371.69 \mathrm{~cd}$ \\
WF - 42 dap & $68.28 \mathrm{~d}$ & $203.01 \mathrm{~d}$ & $313.17 \mathrm{de}$ & $321.69 \mathrm{de}$ & $324.94 \mathrm{de}$ \\
WF - 56 dap & $78.20 \mathrm{~cd}$ & $261.93 \mathrm{bc}$ & $312.80 \mathrm{de}$ & $325.32 \mathrm{de}$ & $333.45 \mathrm{cde}$ \\
WF - 0 dap & $138.95 \mathrm{a}$ & $334.22 \mathrm{a}$ & $555.78 \mathrm{a}$ & $583.57 \mathrm{a}$ & $601.08 \mathrm{a}$ \\
\hline Average & 86.00 & 236.23 & 389.13 & 402.73 & 410.15 \\
\hline CV (\%) & 13.21 & 9.57 & 12.91 & 13.31 & 13.54 \\
\hline
\end{tabular}

Remarks: Number followed by the same letter in the same coloumn indicated that there was no significant difference based on DMRT $\alpha 5 \%$ test; W: weedy after $n$ dap; WF: weed-free after $n$ dap.

significant differences in soil moisture content on the 14 dap to 70 dap. The weed-free treatment from the beginning of the research until the harvest time showed the highest value compared with other treatments.

It was assumed that the soil moisture was only utilised by soybean, so the moisture content in the soil was relatively higher. In a weedy until harvest treatment, the soil moisture content was used by soybean and weeds, causing a relatively lower moisture content compared with other weedy treatments. The degree of crop yield reduction due to weeds interference depended on various factors, such as type of weeds, their density and distribution, time of emergence of weeds relative to crop, as well as soil characteristics such as type, soil moisture status, $\mathrm{pH}$, and fertility level (Papamichail et al., 2002; Bukun, 2004).

Leaf played a very important role. As a photosynthetic organ, it highly determined the growth and development of the plant. Leaf was not only able to produce photosynthate, but also other compounds such as growth hormone (Gardner et al., 1991).

Based on the results of analysis of variance (Table 3), weedy treatment period had a significant effect on soybean leaf area at 14 dap, where the weed-free after 0 dap treatment had the highest leaf area compared with the weed-free after 14 dap, 28 dap, 42 dap, and 56 dap treatments. It was also significantly 
Table 6. Root lenght on various weedy periods of soybean in agroforestry system with kayu putih

\begin{tabular}{lccccc}
\hline \multirow{2}{*}{ Treatment } & \multicolumn{5}{c}{ Root Length (m) } \\
\cline { 2 - 6 } & 14 dap & 28 dap & 42 dap & 56 dap & 70 dap \\
\hline W - 0 dap & $1.00 \mathrm{e}$ & $1.94 \mathrm{e}$ & $3.97 \mathrm{~d}$ & $5.28 \mathrm{c}$ & $5.47 \mathrm{c}$ \\
W - 14 dap & $2.81 \mathrm{bcd}$ & $4.47 \mathrm{~d}$ & $9.58 \mathrm{bc}$ & $12.83 \mathrm{ab}$ & $13.02 \mathrm{ab}$ \\
W - 28 dap & $2.98 \mathrm{cb}$ & $5.87 \mathrm{~b}$ & $9.96 \mathrm{abc}$ & $12.95 \mathrm{ab}$ & $13.02 \mathrm{ab}$ \\
W - 42 dap & $3.09 \mathrm{bc}$ & $6.11 \mathrm{ab}$ & $10.44 \mathrm{ab}$ & $13.86 \mathrm{ab}$ & $14.10 \mathrm{a}$ \\
W - 56 dap & $3.13 \mathrm{bc}$ & $6.13 \mathrm{ab}$ & $10.34 \mathrm{ab}$ & $13.58 \mathrm{ab}$ & $13.76 \mathrm{ab}$ \\
WF - 14 dap & $3.38 \mathrm{ab}$ & $6.28 \mathrm{ab}$ & $10.61 \mathrm{ab}$ & $14.07 \mathrm{a}$ & $14.36 \mathrm{a}$ \\
WF - 28 dap & $2.72 \mathrm{~cd}$ & $5.56 \mathrm{bc}$ & $9.15 \mathrm{bc}$ & $12.01 \mathrm{ab}$ & $12.27 \mathrm{ab}$ \\
WF - 42 dap & $2.38 \mathrm{~d}$ & $5.00 \mathrm{~cd}$ & $7.89 \mathrm{c}$ & $10.66 \mathrm{~b}$ & $10.79 \mathrm{~b}$ \\
WF - 56 dap & $2.78 \mathrm{~cd}$ & $6.32 \mathrm{ab}$ & $8.05 \mathrm{c}$ & $11.79 \mathrm{ab}$ & $12.12 \mathrm{ab}$ \\
WF - 0 dap & $3.75 \mathrm{a}$ & $6.81 \mathrm{a}$ & $11.78 \mathrm{a}$ & $14.85 \mathrm{a}$ & $15.46 \mathrm{a}$ \\
\hline Average & 2.80 & 5.45 & 9.18 & 12.19 & 12.44 \\
\hline CV (\%) & 10.85 & 7.95 & 12.35 & 14.33 & 13.72 \\
\hline
\end{tabular}

Remarks: Number followed by the same letter in the same coloumn indicated that there was no significant difference based on DMRT $\alpha 5 \%$ test; W: weedy after $n$ dap; WF: weed-free after $n$ dap.

Table 7. Root dry weight content on various weedy periods of soybean in agroforestry system with kayu putih

\begin{tabular}{lccccc}
\hline \multirow{2}{*}{ Treatment } & \multicolumn{5}{c}{ Root Dry Weight (grams) } \\
\cline { 2 - 6 } W - 0 dap & $0.39 \mathrm{abc}$ & $0.58 \mathrm{~d}$ & $1.09 \mathrm{~d}$ & $1.36 \mathrm{~d}$ & $1.51 \mathrm{~d}$ \\
W - 14 dap & $0.30 \mathrm{bc}$ & $0.68 \mathrm{~cd}$ & $1.54 \mathrm{bc}$ & $2.01 \mathrm{bc}$ & $2.23 \mathrm{bc}$ \\
W - 28 dap & $0.30 \mathrm{bc}$ & $0.67 \mathrm{~cd}$ & $1.56 \mathrm{bc}$ & $2.04 \mathrm{bc}$ & $2.25 \mathrm{bc}$ \\
W - 42 dap & $0.37 \mathrm{abc}$ & $0.73 \mathrm{bc}$ & $1.66 \mathrm{bc}$ & $2.19 \mathrm{bc}$ & $2.39 \mathrm{bc}$ \\
W - 56 dap & $0.35 \mathrm{abc}$ & $0.81 \mathrm{~b}$ & $1.85 \mathrm{ab}$ & $2.41 \mathrm{ab}$ & $2.60 \mathrm{ab}$ \\
WF - 14 dap & $0.51 \mathrm{abc}$ & $0.82 \mathrm{~b}$ & $1.86 \mathrm{ab}$ & $2.44 \mathrm{ab}$ & $2.61 \mathrm{ab}$ \\
WF - 28 dap & $0.58 \mathrm{ab}$ & $0.67 \mathrm{~cd}$ & $1.51 \mathrm{bc}$ & $1.97 \mathrm{bc}$ & $2.19 \mathrm{bc}$ \\
WF - 42 dap & $0.28 \mathrm{c}$ & $0.64 \mathrm{~cd}$ & $1.38 \mathrm{~cd}$ & $1.78 \mathrm{~cd}$ & $2.00 \mathrm{c}$ \\
WF - 56 dap & $0.38 \mathrm{abc}$ & $0.64 \mathrm{~cd}$ & $1.36 \mathrm{~cd}$ & $1.74 \mathrm{~cd}$ & $1.94 \mathrm{~cd}$ \\
WF - 0 dap & $0.61 \mathrm{a}$ & $0.94 \mathrm{a}$ & $2.13 \mathrm{a}$ & $2.72 \mathrm{a}$ & $2.90 \mathrm{a}$ \\
\hline Average & 0.41 & 0.72 & 1.59 & 2.06 & 2.26 \\
\hline CV (\%) & 36.62 & 9.24 & 12.04 & 12.35 & 11.51 \\
\hline
\end{tabular}

Remarks: Number followed by the same letter in the same coloumn indicated that there was no significant difference based on DMRT $\alpha$ 5\% test; W: weedy after $n$ dap; WF: weed-free after $n$ dap.

different from the weed after 0 dap, 14 dap, 28 dap, 42 dap, and 56 dap treatments. However, at the age of $28,42,56$, and 70 dap, each treatment had no significant effect on leaf area of soybean.

Chlorophyll was a determinant element on the plant's photosynthesis ability which was mostly found in leaves. The content of chlorophyll in the leaves was closely related to the leave's greenness. The higher the chlorophyll content, the higher the photosynthesis ability. According to Taiz and Zieger (2002) concerning photosynthesis process, chlorophyll was a complex molecule which played a role in capturing solar energy and transfering energy and electron.

The results of analysis of variance (Table 4) showed that the weedy period treatment had a significant effect on the contents of chlorophyll a, chlorophyll $\mathrm{b}$, and total chlorophyll of soybean. The contents of chlorophyll a, chlorophyll b, and total chlorophyll in weed-free until the harvest treatment were higher than any other weedy treatment.

This was presumably due to the competition for nutrients, one of which was nitrogen that influence the chlorophyll content in soybean. The availability of essential nutrients was one of the many site-specific factors which directly influence the outcome of crop-weed interference of a particular site (DiTomaso, 1995; Evans et al., 2003; Leskovsek et al., 2012). Nitrogen (N) was the major nutrient applied to increase crop 
Table 8. Shoots dry weight content on various weedy periods of soybean in agroforestry system with kayu putih

\begin{tabular}{lccccc}
\hline \multirow{2}{*}{ Treatment } & \multicolumn{5}{c}{ Shoots Dry Weight (grams) } \\
\cline { 2 - 6 } & 14 dap & 28 dap & 42 dap & 56 dap & 70 dap \\
\hline W - 0 dap & $0.89 \mathrm{abc}$ & $2.66 \mathrm{c}$ & $3.16 \mathrm{c}$ & $3.47 \mathrm{c}$ & $7.61 \mathrm{~d}$ \\
W - 14 dap & $0.43 \mathrm{~d}$ & $3.63 \mathrm{bc}$ & $4.85 \mathrm{bc}$ & $4.92 \mathrm{bc}$ & $13.10 \mathrm{bcd}$ \\
W - 28 dap & $0.80 \mathrm{a}-\mathrm{d}$ & $3.68 \mathrm{bc}$ & $4.94 \mathrm{bc}$ & $5.00 \mathrm{bc}$ & $13.37 \mathrm{bcd}$ \\
W - 42 dap & $0.54 \mathrm{~cd}$ & $4.03 \mathrm{bc}$ & $5.54 \mathrm{bc}$ & $5.53 \mathrm{bc}$ & $15.09 \mathrm{bc}$ \\
W - 56 dap & $0.53 \mathrm{~cd}$ & $4.83 \mathrm{~b}$ & $6.98 \mathrm{~b}$ & $6.91 \mathrm{~b}$ & $18.80 \mathrm{~b}$ \\
WF - 14 dap & $0.60 \mathrm{bcd}$ & $4.86 \mathrm{~b}$ & $7.04 \mathrm{~b}$ & $6.94 \mathrm{~b}$ & $19.00 \mathrm{~b}$ \\
WF - 28 dap & $1.00 \mathrm{a}$ & $3.57 \mathrm{bc}$ & $4.74 \mathrm{bc}$ & $4.83 \mathrm{bc}$ & $12.74 \mathrm{bcd}$ \\
WF - 42 dap & $1.01 \mathrm{a}$ & $3.23 \mathrm{c}$ & $4.13 \mathrm{c}$ & $4.31 \mathrm{c}$ & $10.90 \mathrm{~cd}$ \\
WF - 56 dap & $0.65 \mathrm{a}-\mathrm{d}$ & $3.21 \mathrm{c}$ & $4.11 \mathrm{c}$ & $4.29 \mathrm{c}$ & $10.74 \mathrm{~cd}$ \\
WF - 0 dap & $0.96 \mathrm{ab}$ & $6.42 \mathrm{a}$ & $9.83 \mathrm{a}$ & $9.97 \mathrm{a}$ & $25.65 \mathrm{a}$ \\
\hline Average & 0.74 & 4.01 & 5.53 & 5.62 & 14.70 \\
\hline CV (\%) & 26.54 & 18.07 & 23.37 & 23.32 & 22.99 \\
\hline
\end{tabular}

Remarks: Number followed by the same letter in the same coloumn indicated that there was no significant difference based on DMRT a 5\% test; W: weedy after $n$ dap; WF: weed-free after $n$ dap.

Table 9. Delta of seeds dry weight per hectare decreased on various weedy periods of soybean in agroforestry system with kayu putih

\begin{tabular}{cccc}
\hline \multirow{2}{*}{ Treatment } & $\begin{array}{c}\text { Weeds Dry Weight } \\
\text { per Hectar (ton/ha) }\end{array}$ & $\begin{array}{c}\text { Seeds Dry Weight per } \\
\text { Hectar (ton/ha) }\end{array}$ & $\begin{array}{c}\Delta \text { Decrease of Yield a } \\
\text { result by Weeds (\%) }\end{array}$ \\
\hline WF 0 dap & $0.00 \mathrm{e}$ & $2.00 \mathrm{a}$ & 0.00 \\
WF 14 dap & $5.13 \mathrm{ab}$ & $1.53 \mathrm{ab}$ & 23.50 \\
WF 28 dap & $2.00 \mathrm{~cd}$ & $1.03 \mathrm{bcd}$ & $48.50^{*}$ \\
WF 42 dap & $3.50 \mathrm{bc}$ & $0.86 \mathrm{~cd}$ & $57.00^{*}$ \\
WF 56 dap & $5.13 \mathrm{ab}$ & $0.84 \mathrm{~cd}$ & $58.00^{*}$ \\
W 0 dap & $6.86 \mathrm{a}$ & $0.56 \mathrm{~d}$ & $72.00^{*}$ \\
W 14 dap & $1.84 \mathrm{~cd}$ & $1.08 \mathrm{bcd}$ & $46.00^{*}$ \\
W 28 dap & $1.42 \mathrm{cde}$ & $1.10 \mathrm{bc}$ & $45.00^{*}$ \\
W 42 dap & $1.01 \mathrm{de}$ & $1.25 \mathrm{bc}$ & $37.50^{*}$ \\
W 56 dap & $0.18 \mathrm{e}$ & $1.53 \mathrm{ab}$ & 23.50 \\
\hline
\end{tabular}

Remarks: Number followed by same letter in same coloumn indicates no significantly different based on DMRT $\alpha 5 \%$ test; W: weedy after $n$ dap ; WF: weed-free after $n$ dap; $\left({ }^{*}\right)$ : Significan different with control (WF after 0 dap).

yield. However, weed demographic processes and crop-weed competitive interactions were affected by changing $\mathrm{N}$ levels in soil (Camara et al., 2003; Blackshaw et al., 2004).

Root was the main vegetative organ which supplied water, minerals, and materials which were essential to the growth and development of the plants. A strong root growth was necessary for the strength and growth of shoots. The roots might be damaged due to the disruption of biological, physical, or mechanical and less work, then growth will be reduced (Gardner et al., 1991).

Based on the analysis of variance (Table 5), the weedy period treatment had a significant effect on the root's surface area at the age of 14 to 70 dap. The weed-free until the harvest time treatment had the highest root's surface area compared with 9 weedy period treatments at all observation periods. Meanwhile, the weedy until the harvest time treatment had the lowest roots surface area at all observation periods. This was caused by the soybean plants grown on a weedy land, there would be a competition for nutrients, water, and place to growth with weeds growing around.

This resulted in the obstruction in plant growth, indicated by roots which were unable to absorb nutrients and water optimally. However, when the soybean plants grew on a weed-free land until the harvest, the plants could optimally absorb the nutrients contained in the soil without any competitors so that the growth 


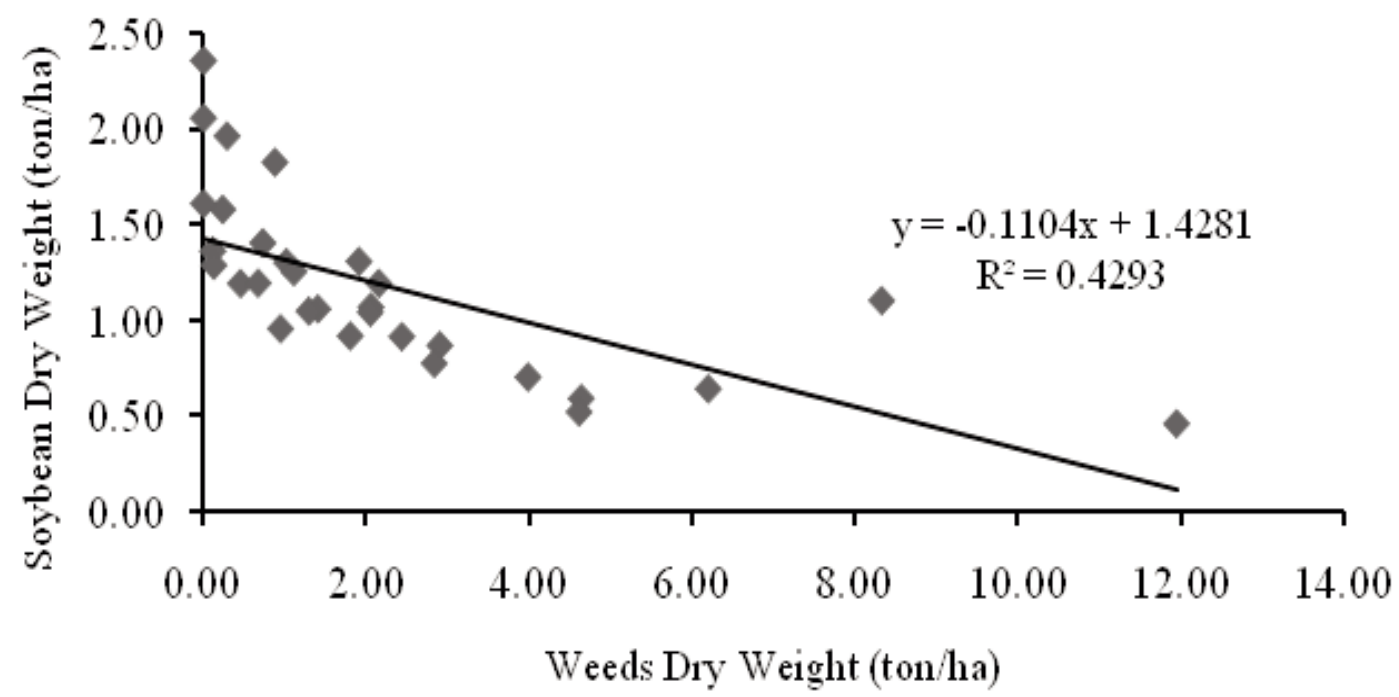

Figure 1. Regression analysis between weeds dry weight with soybean dry weight

was better than nine other treatments.

Analysis of variance (Table 6) showed that the weedy period treatment had a significant effect on roots length of soybean. Weedy period had an effect when plants were at the ages of 14. 28. 42.56. and 70 dap. where the weed-free until harvest treatment had the longest roots at the age of 14 to 70 dap compared with nine other treatments. In addition. the weedy until the harvest treatment had the shortest roots at all ages. It was presumably due to the competition of growing space which resulted in weedy soybean's inability to develop its roots optimally and thus affected root length.

Analysis of variance result (Table 7) showed that the weedy period treatment had a significant effect on the dry weight of soybean roots at all observed ages. The weed-free until the harvest treatment generated the highest roots dry weight compared with other weedy treatments. When the soybean could grow normally without any weeds growing around, it would affect the root growth. The roots of soybean could grow well and were able to absorb nutrients and water optimally when there was no competitor. the weeds. Therefore. the dry weight of roots was also higher than the roots of soybean with weedy treatment. It was proved that the soybean in the weedy until the harvest treatment had the smallest roots dry weight at the age of 28 to 70 dap.

This was caused when plants were in their vegetative phase. The weeds put pressure on soybean to produce carbohydrates from photosynthesis which were mostly used for cell division. cell elongation. and the growth of roots. stems. and leaves.

The results of this research showed that longer weedy period resulted in higher diversity of weed species compared with shorter weedy period. The weeds which grew before harvest time led to a lower diversity of weed species to appear. The longer the weeds grew in soybean plantation. the greater the competition that resulted in more obstruction of growth and lower product components. The weed competition in the early growth period would reduce the product's quantity. while the competition near harvest time affected the product's quality.

The results of this research showed that the critical period of soybean began at $40-70 \%$ of its age. It was different from the research conducted by Hendrival et al. (2014). Zimdahl (2004). and Mercado (1979). Hendrival et al. (2014) stated that the critical period of soybean against weed competition occured in 14-42 dap. Meanwhile Zimdahl (2004) stated that the critical period occured in the $25 \%-33 \%$ of plant's first life cycle. Mercado (1979) stated that the critical period ranged from $33 \%-50 \%$ of the plant's age. It was possibly due to the interaction between genetic and environmental factors.

\section{CONCLUSION}

There was a significant difference in moisture of soil, root surface area, root length, chlorophyll content, root dry weight, shoot dry weight, dry weight of soybean seeds, and weed dry weight. The highest seed weight per hectare was shown in weed-free until harvest treatment, but it was not significantly different from the weeded plants after 56 days after planting and weed free after 14 days after planting. The appropriate period of weeding time for soybean in agroforestry systems with kayu putih began at 28 - 56 days after planting.

\section{ACKNOWLEDGEMENT}

The author would like to express his profuse 
thanks to LPPM (Agency for Research and Community Service) UGM which had funded this research through the university grant-in-aid scheme (No: LPPM-UGM/371/LIT/2014).

\section{REFERENCES}

Amador-Ramírez, M. D. 2002. Critical Period of Weed Control in Transplanted Chilli Pepper. Weed Res., 42: 203-209.

Arslan, M., I. Uremis, and A. Uludag. 2006. The Critical Period of Weed Control in Double-Cropped Soybean. Phytoparasitica, 34 (2): 159-166.

BPS. 2014. Kedelai. [online] Available at: http://www.bps.go.id/tnmn pgn.php/ [Accessed 18 September 2016].

Blackshaw, R.E. 2004. Application Method of Nitrogen Fertilizer Affects Weed Growth and Competition with Winter Wheat. Weed Biology Management, 4 (2): 103-113.

Blackshaw, R. E., L. J. Molnar, H. H. Janzen. 2004. Nitrogen Fertilizer Timing and Application Method Affect Weed Growth and Competition with Spring Wheat. Weed Science, 52(4): 614622.

Bukun, B. 2004. Critical Periods for Weed Control in Cotton in Turkey. Weed Research, 44(5): 404-412.

Camara, W. A., P. E. Payne, Rasmussen. 2003. Long-term Effects of Tillage. Nitrogen Rainfall and Nitrogen Levels on Wheat Yield. Agronomy Journal, 95: 823-835.

Cardoso, G. D., P. L. C. A. Alves, L. S. Severino, and L. S. D. Vale. 2011. Critical Periods of Weed Control in Naturally Green Colored Cotton BRS Verde. Ind Crops Prod., 34: 1198-1202.

DiTomaso, J. 1995. Approaches for Improving Crop Competitiveness through The Manipulation of Fertilization Strategies. Weed Sci., 43: 491497.

Evan, S. P., S. Z. Knezevic, J. L. Lindquist, C. A. Shapiro, and E. E. Blankenship. 2003. Nitrogen Application Influences The Critical Period for Weed Control in Corn. Weed Science, 51(3): 408-417.

Gardner, F. P., R. B. Pearce, dan R. L. Mitchell. 1991. Fisiologi Tanaman Budidaya. In: Susilo, Herawati, ed., Fisiologi Tanaman Budidaya Terjemahan ed. Jakarta: UI Press.

Hall, M. R., C. J. Swanton, and G. W. Anderson. 1992. The Critical Period of Weed Control in Grain Corn (Zea mays). Weed Science, 40(3): 441-447.

Hendrival, Z. Wirda, dan A. Azis. 2014. Periode Kritis Tanaman Kedelai terhadap Persaingan Gulma. Jurnal Floratek, 9(1): 6-13.
Johu, P. Y. Sugito, dan B. Guritno. 2002. Pengaruh Populasi dan Jumlah Tanaman Per Lubang Tanaman Jagung (Zea mays L.) dalam Pola Tumpangsari dengan Kacang Buncis (Phaseolus vulgaris L.) terhadap Pertumbuhan dan Hasil Tanaman. Agrivita, 24(1):17 -24.

Knezevic, S. Z., S. P. Evans, and M. Mainz. 2003. Row Spacing Influences The Critical Timing for Weed Removal in Soybean (Glycine max). Weed Technology, 17(4): 666-673.

Kramer, P. J. 1969. Plant and Soil Water Relationships: A Modern Synthesis. In: Kramer, P. J., ed., Plant and Soil Water Relationships Reprinter in India arrangement with Mc. Graw - Hill. Inc. New York, Sidney: Mc. Graw-Hill Inc., pp. 482.

Leskovšek, R., A. Datta, A. Simoncic, and S. Z. Knezevic. 2012. Influence of Nitrogen and Plant Density on The Growth and Seed Production of Common Ragweed (Ambrosia artemisiifolia L.). J. Pest Sci., 85: 527-539.

Mercado, B. L. 1979. Introduction to Weed Science. Philipines: SEARCA Publication, pp. 282-308.

Moenandir, J. 1993. Pengantar Ilmu dan Pengendalian Gulma. Jakarta: PT. Rajawali Press.

Papamichail, D., I. Eleftherohorinos, R. Froud-Williams, and F. Gravanis. 2002. Critical Periods of Weed Competition in Cotton in Greece. Phytoparasitica, 30(1): 1-7.

SAS Institute. 1994. SAS User's Guide. USA, NC: SAS Inst. Cary.

Scholes, R. J. and B. H. Walker. 1993. An African Savanna: Synthesis of The Nylsvley Study. New York: Cambridge University Press, pp. 320.

Soil Survey Staff. 2010. Key to Soil Taxonomy. USA: United States Department of Agriculture Natural Resources Conservation Service.

Swanton, C. J. and S. F. Weise. 1991. Integrated Weed Management: The Rationale and Approach. Weed Technol, 5(3): 657-663.

Taiz, L. and E. Zeiger. 2002. Plant Physiology Third Edition. Sunderland, Massachusets: Sinauer Associates. Inc.

Tursun, N., A. Datta, E. Tuncel, Z. Kantarci, and S. Z. Knezevic. 2015. Nitrogen Application Influenced the Critical Period for Weed Control in Cotton. Crop Prot., 74: 85-91.

Tursun, N., A. Datta, S. Budak, Z. Kantarci, and S. Z. Knezevic. 2015. Row Spacing Impacts The Critical Period for Weed Control in Cotton (Gossypium hirsutum). Phytoparasitica 44: 139-149.

Uremis, I., A. Uludag, A. C. Ulger, and B. Cakir. 2009. Determination of Critical Period for 
Weed Control in The Second Crop Corn under Mediterranean Conditions. African Journal of Biotechnology, 8(18): 4475-4480.

Van Acker, R. C., C. J. Swanton, and S. Weise. 1993. The Critical Period of Weed Control in Soybean [Glycine $\max$ (L.) Merr.]. Weed Science, 41(2): 194-200.

Weaver, S. E. and C. S. Tan. 1983. Critical Period of Weed Interference in Transplanted Tomatoes (Lycopersicon esculentum): Growth Analysis. Weed Sci, 31: 476-481.
Zimdahl, R. L. 1980. Weed Crop Competition A Review. Oregon: Publ. In U.S. by The I.P.P.C, pp. 195. Zimdahl, R. L. 1988. The Concept and Application of the Critical Weed-Free Period. Florida, USA: CRC Press Inc., pp. 145-155.

Zimdahl, R. L. 1993. Fundamentals of Weed Science. USA: Academic Press, San Diego, CA.

Zimdahl, R. L. 2004. Weed-Crop Competition: a Review Second Edition. Australia: Blackwell Publishing. 